\title{
EVALUATION OF SEISMIC HAZARD USING TECTONIC FAULT DATA: CASE OF BENI-CHOUGRANE MOUNTAINS (WESTERN ALGERIA)
}

\author{
Soraya $\operatorname{REFAS}^{1 *}$, Aissa SAFA ${ }^{2}$, Mansour ZAAGANE $^{1}$, \\ Zahera SOUIDI $^{1}$, Abderahmane HAMIMED ${ }^{1}$ \\ ${ }^{1}$ Research Laboratory of Biological Systems and Geomatics (LRSBG), University of Mascara, Mascara, \\ Algeria \\ ${ }^{2}$ Laboratory of Hydrogeology, Mohamed Ben Ahmed, University,Oran-2, Oran, Algeria
}

\begin{abstract}
In the world, people are increasingly exposed to natural hazards such as earthquakes. To this end, seismic risk mapping remains an essential topic of study in order to minimize their destructive effects. These maps are needed for both seismic risk management and for the design of infrastructure. The challenge is to take into account local information provided by seismic sources (historical seismicity) as well as information related to active tectonic faults.

In this article, we calculated the seismic risk in the Mascara Mountains (western Algeria) using the geometric characteristic of known faults. This study is based on an important collection of a tectonic database of these faults (Nature, geometry and geological context). This information is relevant for their seismic potential. Indeed, by including these formations we tried to compute the seismic risk this region characterized by weak seismicity. Our results show more or less alarming facts. Indeed, the magnitude values calculated are between 4.85 and 7.25 , whereas the magnitudes obtained by experimental seismicity do not exceed 6 on the Richter scale. The values of the maximum ground acceleration (PGA) are between 0.03 and $0.28 \mathrm{~g}$. These results were compared with assessments made on the basis of historical seismicity; the maximum values obtained do not exceed $0.2 \mathrm{~g}$. The higher values of magnitude calculated from the active faults is due to: (i) the nature of the faults (inverse, normal and strike slip), (ii) the geometry (length and depth) and (iii) that some of these faults may have an aseismic character.
\end{abstract}

Keywords: earthquake, magnitude, peak ground acceleration, active faults, Mascara region

*Corresponding authors: soria_r5@yahoo.fr(S. Refas)

doi: $10.37190 / \mathrm{msc} 192609$ 


\section{INTRODUCTION}

In northern Algeria, natural hazards usually have terrible consequences both physically and in terms of loss of life; however, their suddenness, their spatio-temporal occurrence, and their magnitude are the interesting characteristics that scientists devote considerable effort to studying to minimize their devastating effects. These natural phenomena are represented by earthquakes, landslides, landslides, landslides and debris flow. These major risks cause considerable damage that sometimes exceeds the reactions of the authorities concerned (Hadji et al. 2013; Hadji et al. 2017; Manchar et al. 2018; Mahdadi et al. 2018; Karim et al. 2018).

Located in the tellian chain of Algeria, in $100 \mathrm{~km}$ of the south of Oran, the Beni-Chougrane Mountains constitute a veritable mountainous chain oriented ENE WSW (Fig. 1). There are structured during the neotectonic period especially during the Pliocene to the Pleistocene (Perrodon 1957; Delteil 1972; Thomas 1985; Neurdin Trescartes 1993; Moussa 1996). Consequently, the compressive tectonic regime affected this zone and produced the exhumation of these mountains. Indeed, the Pliocene formations are situated locally in $900 \mathrm{~m}$ in altitude related to the same formations located in the Habra plain $(\sim 50 \mathrm{~m})$, this difference of altitude show the strongest plio-quaternary tectonic very big exhumation $(\sim 900 \mathrm{~m})$ in fewer times ( $\sim 5$ my). This ascertainment show the importance of tectonic activity as reverse and strike slip faults (Bezzeghoud et al. 1999; Ayadi et al. 2002). The southern part of Beni-Chougrane Mountains is linked to the Ghriss plain by continuous folding. These folds are materialized by reverse fault directly in contact with the quaternary formation.

It is in this perspective that the present work focuses on the evaluation of seismic risks, which is based in some way on seismicity directly from the seismic source (active fault). Historical seismicity is often used as a reference for these calculations. The results obtained are often due to data errors related to earthquake parameters, or the parameters calculated from these data (i.e., magnitude, location, and Gutenberg-Richter values, $a, b$, and $\left.M_{\max }\right)$ and lack of knowledge about mitigation relationships governing each area (Paleez et al. 2003). To reduce this uncertainty and to optimize the real value of magnitudes and PGA, we used for the first time a recent database of active faults in the Beni-Chougrane Mountains (Dalloni 1936; Perrodon 1957; Delteil 1972; Thomas 1985; Neurdin Trescartes 1993). We provide a new earthquake source model for assessing the seismic hazard of this region. The magnitude values are obtained by several regression models (Esteva and Rosenblueth 1964; McGuire 1976; Slemmons 1977; Campbell 1981; 1988; 1997; 1982; Nuttli 1983; Well and Copersmith 1994; Xiang and Gao 1994; Vakov 1996; Stirling et al. 1996; Ambraseys and Jackson 1998; Wenousky 2008; Dowrick and Rhoades 2004; Strasser et al. 2010). However, the PGA values are directly derived from the data of faults according to different model (Cornell 1968; Esteva and Rosenblueth 1974; 
McGuire 1976; Campbell 1981a; Campbell 1981b; Campbell 1981c; WoodwardClyde 1983; Campbell 1988; Idriss 1993; Xiang and Gao 1994; Ambraseys 1995; Campbell 1997).

The results are then compared with previous seismic hazard assessments obtained on the historical seismicity (Bezzeghoud et al. 1999; Ayadi et al. 2002).

It is in this perspective that this work focuses on the evaluation of seismic risks which is based in some way on the seismicity directly derived from the seismic source (fault data). Historical seismicity is often used as a reference for these calculations.

To try to reduce this uncertainty and to optimize the real value of magnitudes and PGA, we used for the first time a recent database of faults in the Beni-Chougrane Mountains () to provide a new earthquake source model for assessing the seismic hazard of the region. The seismicity, the PGA are directly derived from the data of faults according to different model (Esteva and Rosenblueth 1964; Cornell 1968; McGuire 1976; Slemmons 1977; 1982, Campbell 1981; 1988; 1997; Nuttli 1983; Woodward and Clyde 1983; Wenousky et al. 1983; Idriss 1985; Well and Copersmith 1994; Xiang and Gao 1994; Ambraseys 1995; Vakov 1996; Stirling et al. 1996; Ambraseys and Jackson 1998; Dowrick and Rhoades 2004; Strasser et al. 2010). The results are then compared with previous seismic hazard assessments obtained on the basis of historical seismicity (Bezzeghoud et al. 1999; Ayadi et al. 2002).

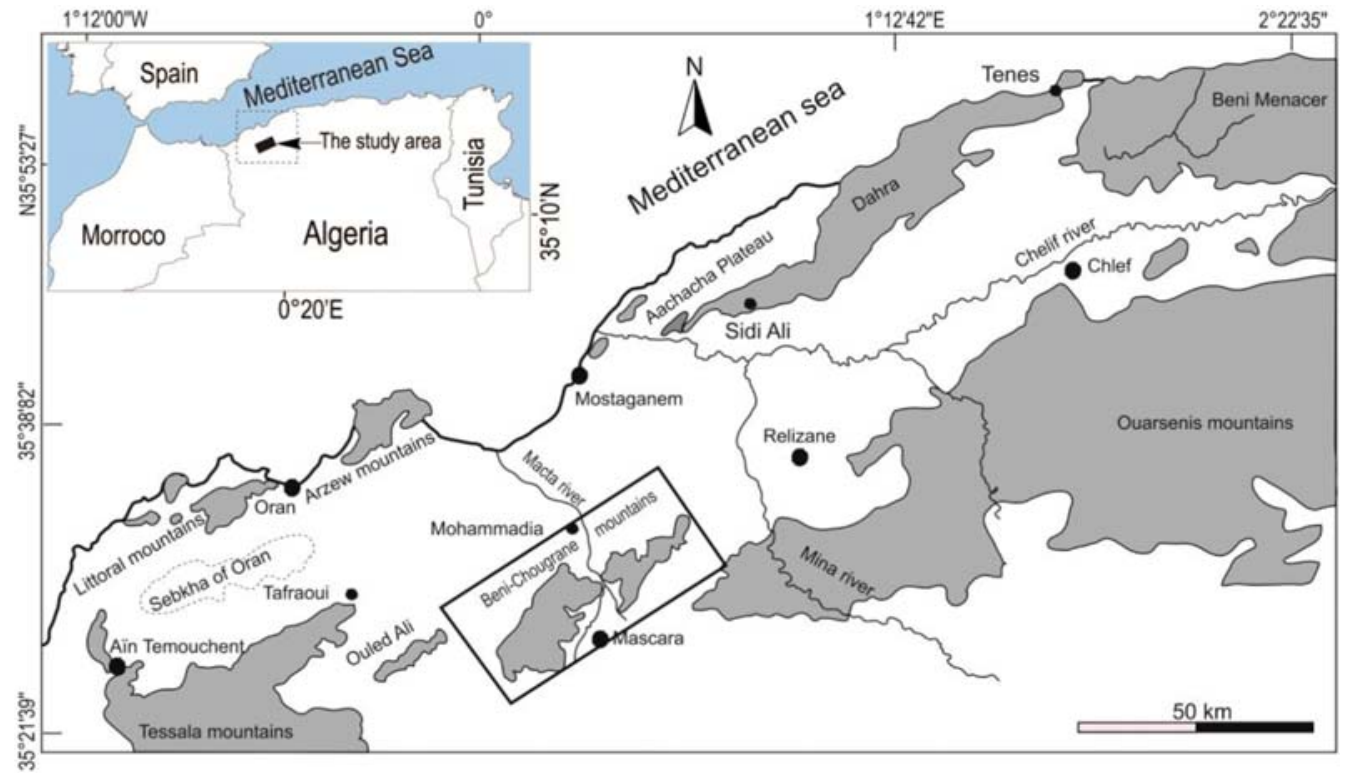

Fig. 1. Geographical situation of Beni-Chougrane Mountains. The grey color represents the tellian chain of the west Algeria 


\section{SEISMIC HISTORY}

In the Beni-Chougrane Mountains, historical seismicity reveals strong intensity earthquakes. Indeed, we quote various case like the earthquake that occurred in March 1819 characterized by an intensity of $I_{o}=\mathrm{X}$, relative to the scale of Merkali (MKS) or the earthquake of November 22th, $1851\left(I_{o}=\right.$ VIII) as well as the last one happened in November 29th $1887\left(I_{o}=\right.$ X) (Rothé 1950; Harbi 2006; Yeles Chouech 2006).

In this zone, the recent seismic period is characterized by a moderate and very active seismicity. Indeed, the city of Sig, situated in a few kilometers in the Northwest of Mascara, have also been hit, on July 13th, 1967, by an earthquake whose magnitude was evaluated at 6.1 ( $I_{o}=$ VII-VIII) (McKenzi 1972). In August 18th,



Fig. 2. Seismtectonic maps for Beni-Chougrane Mountains representing focal mechanisms and main geological faults. Other focal mechanisms for these areas are shown with smaller size of the focal sphere (FM) established by Meckenzie (1972) for the 1967 earthquake, Bezzeghoud and Buforn (1999) for the 1994 earthquake. Arrows show direction of actual stress (black arrow) in this area (Meghraoui and Pondrelli (2013). Open circles represent the seismicity for the period 1990 to present times (USGS and Benouar data file), the black and white circles are respectively the 1967 and 1994 earthquakes. Grey, white, blue and green Stars show the epicenters of 1994 earthquake event registered, respectively, by USGS, CRAAG, Global CMT centers and Bezzeghoud and Buforn (1999). $\mathrm{a}, \mathrm{b}$ and $\mathrm{c}$ represent magnitude of earthquake greater than 4 , between 4 and 2 and less than 2 , respectively. The scheme in the bottom right map show the actual tectonic regime affecting the Beni-Chougrane area according to Meghraoui and Pondrelli (2013) 

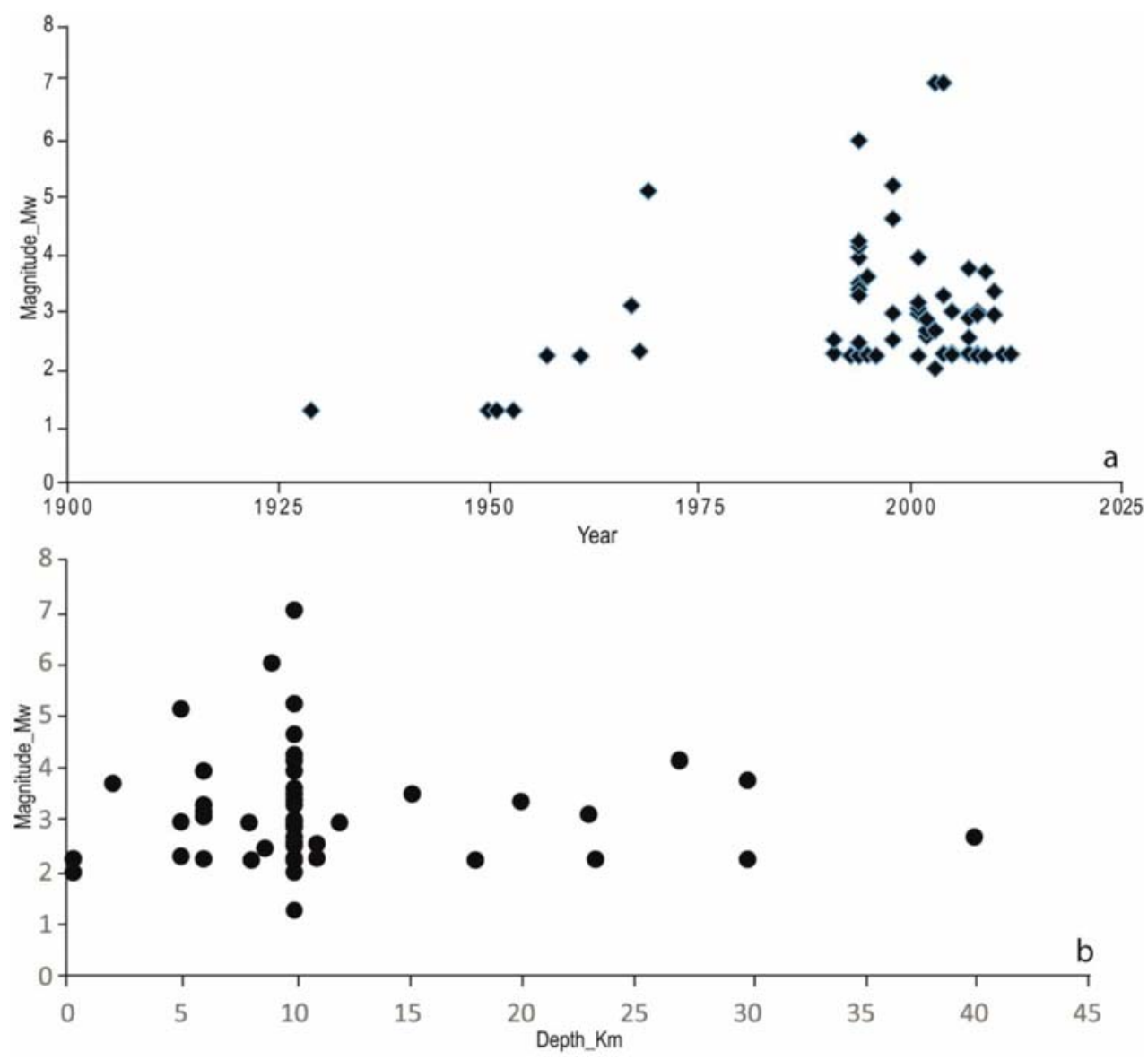

Fig. 3. Diagram showing the earthquake repartition:

$\mathrm{a}-$ in the times scale and $\mathrm{b}$ - the relationship between the magnitude and the depth

1994, this region was again affected by another earthquake which is characterized by a magnitude of 5.8 (Fig. 1). Several seismological centers (Global CMT, USGS, CRAAG) proposed different locations of this earthquake epicenter (Fig. 1). The estimated seismic moment is $6.8 \times 10^{17} \mathrm{Nm}(\mathrm{Mw}$ 5.8, Global CMT). Bezzeghoud and Buforn (1999) calculate a seismic moment of $3.3 \times 10^{17} \mathrm{Nm}$ from the waveform analysis and $5.6 \times 10^{17} \mathrm{Nm}$ from the spectral analysis respectively corresponding to magnitudes of moment (Mw) of 5.6 and 5.8 (Bezzeghoud et al. 1996). All the focal mechanisms show that this earthquake was generated by a reverse fault oriented ENE-WSW in about $20 \mathrm{~km}$ of length (Global CMT, Bezzeghoud and Buforn 1999) (Fig. 2). This earthquake caused extensive material and human damage. The main shock, lasting around 12 seconds, killed 171 people and injured 654 people, 289 of whom were seriously injured. Several houses and farms (2000) were seriously de- 
stroyed including ten schools (Fig. 2). Therefore 1328 families (12 500 people) remained homeless in summer season (Benouar 1994). However, it did not induce surface traces only a few cracks and landslides were reported (Bezzeghoud and Buforn 1999; Benouar et al. 1994).

Recently, a magnitude 4.4 earthquake occurred on August 17th, 2005. This earthquake was located at the eastern part of the Beni-Chougrane Mountains, not far from the famous epicentral zone of the earthquake of August 18th, 1994.

The most important of these earthquakes are registered in the period from 1975 to present day (Fig. 3a). We can explain this reality by the scientific progress and else the effort that the worldwide give to this phenomena to minimized there big damage by preparing the civic society (Fig. 2). These earthquakes are not deepest, indeed the structure of Beni-Chougrane is as ridge bordered two separated basin (Habra plain and Ghriss plain). As in the external tellian chain, this area is affected by overlap with south vergence; this structure is in favor of a fault which becomes plate in the deepest. We think that only the fault that constitute the Beni-Chougrane borders in the south and in the north are very deepest, the rest are very superficial and generate this superficial seismicity (Fig. 3b).

\section{GEOLOGICAL SETTING}

\subsection{STRUCTURAL FRAMEWORK}

The Beni-Chougrane Mountains are formed of much folded geological formations with a Cretaceous basement and a very thick Cenozoic cover.

Cretaceous marl and limestone marl are characterized by Triassic gypsiferous uplifts along the abnormal contacts that overlie the marly Miocene formation (Fig. 4). Nummulitic (Eocene and Oligocene), marl and sandstone, is in contact with Cretaceous or Miocene formations (Fig. 4). These Neogene beds, slightly wrinkled, currently cover, almost entirely, the southern border of the Beni-Chougrane Mountains (Bekkoussa et al. 2013).

The Beni-Chougrane Mountains, arranged in the Cenozoic folding fold, are oriented ENE/WSW thus separating two large structural units belonging to the Lower Chelif basin (Thomas 1985; Neurdin Trescartes 1992). These include the southern sillon represented by the Ghriss Plain, and the northern sillon represented by the Habra Plain.

The first ridge corresponds to a fold with a very deformed Cretaceous nucleus, this nucleus outcrops to the East under marl-limestone in decametric banks (Fig. 5a). This outcrop becomes more important and outcrops largely in the center of the Beni-Chougrane area beyond Dj Bouziri (Fig. $5 b$ and c). The southern bank of the Beni-Chougrane Mountains is characterized by an upper Miocene cover arranged in a less rectified synclinal form (Fig. 5d). 


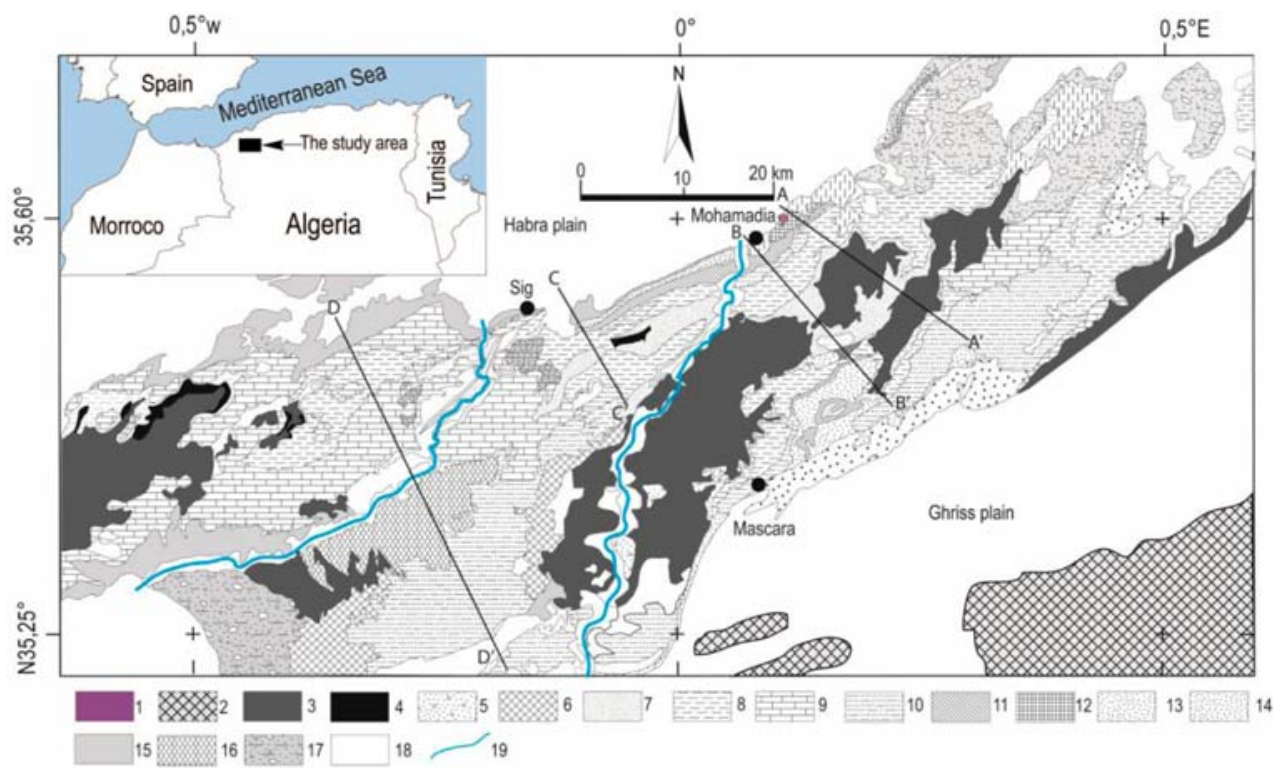

Fig. 4. Simplified geological map of the Beni-Chougrane Mountains (geographic coordinates): 1 - eruptive rocks; 2 - Jurassic limestones, 3 - ante-nappes formations; 4 - marl (early Miocene); 5 - conglomerate and sandstone (early Miocene); 6 - continental formation of Bou Hanifia; 7 - basis sandstone; 8 - Bleu marl; 9 - Lithothamny limestone; 10 - El bordj sandstone formation; 11 - diatomitic formation; 12 - gypsium and marly gypsifourous; 13 - bleu marl; 14 - sea sandstone; 15 - continental sandstone and silt at Helix; and 16 - lake deposit; 17 - limestone crust; 18 - alluvium; 19 - watercourse. The black line disposed perpendicular to in the map represent the geological cross section showing in Fig. 5


Fig. 5. Cross-section along the Beni-Chougrane Mountains showing the geologic features (before and after-nappes). For the abbreviations, ANT and SNL are respectively anticline and synclinal, BG is Bel Ghrib, MRDJ is Merdja, CRBH is Cherb Errih. FRG is Fergoug, PRG is Mohammadia O. is Oued e.g. (rivers). 
This structure is disturbed by secondary structures of anticlines and synclines interlinked within the same structure (Fig. 5). These structures are essentially formed by Plio-Quaternary formations (Fig. 5). These include the anticlinal of Bou Ziri, Merdja, and synclines such as those of Dzkeria, Bel Ghribe (Fig. 2, 5c), synclinal perched of Gaada and that of Sfisef (Fig. 2, 5d).

The Cretaceous skeleton is largely covered by recent Cenozoic formations. The Mekkera River reveals a very restricted window of this framework (Fig. 4).

\subsection{TECTONIC FRAMEWORK}

The late tectonic activity which is responsible of the uplifting of the Beni-Chougrane Mountains was characterized by compressive regime. Indeed, there are several clearly active faults in this region, which on the whole facilitate uplifting of the Beni-Chougrane blocks along folding and high reverse faults which framework these mountains from the North, the South and also in the West (Fig. 2). The existence of these faults was demonstrated by several authors (Perrodon 1955; Delteil 1972; Thomas 1985; Neurdin 1993).

The southern part of Beni-Chougrane is limited by the fault of Ain Fekan which is the relay of Sidi Belabes fault; it is in particular a right strike slip fault inducing the torsion of the folds in its neighborhood and by the Ain fares fault oriented $\mathrm{N} 140^{\circ}$. Two sets can be attributed: (i) a relatively narrow folded complex (4 to $5 \mathrm{~km}$ ) extending over $40 \mathrm{~km}$ and whose orientation goes from $\mathrm{N} 50^{\circ}$ to $\mathrm{N} 20^{\circ}$ under the influence of the Mascara-Sidi Ali transverse and (ii) a developed area North-east of Mascara where the folded structures are discontinuous. There are also $\mathrm{N} 20^{\circ}$ strike slip faults that are probably influenced by deeper accidents (Fig. 2).

The eastern sector has offered structures associated with NE/SW oriented reverse faults. Several faults especially those that are oriented N140 ${ }^{\circ}$ cut this sector (Fig. 2). However, no torsion is found which indicates that the horizontal movement is very small. These faults probably correspond to the cutting of the base by old accidents (Thomas 1985).

\section{METHODOLOGY AND DATA PROCESSING}

\subsection{FAULTS MAPPING}

The tectonic nature and length of active faults used are presented in this work are based essentially on the ancient works (Daloni 1936; Delteil 1972; Thomas 1985; Neurdin 1993) (Fig. 1).

To inventory faults, we are based on oldest files for sample: (i) geological maps (Daloni 1936; Delteil 1972; Thomas 1985; Neurdin 1992), (ii) oldest study reports (railway and dams) and (iii) geophysical study for hydro-geological purpose (2ème 
rapport 1969). However, microtectonic indexes have been everywhere observed, in this zone affecting generally the recent formations. These indices show both straie with horizontal pitch indicating strike-slip faults and vertical component straie, thus showing normal or reverse faults. We proceeded to locate the observed faults by using GPS (Global position systems). The maps were wedged in a preferential projection system (UTM fuseau 31), then we traced, in vector format. On a drawing layer, the faults were superimposed on the geological map. All data coming from this study have been reported in Table 1. Indeed, the necessary information such as length and nature has been assigned for each of these faults. Lengths were calculated from georeferenced maps; however, nature was determined in basis of the geological map and also the disposition of the faults according to the current stress $\left(\mathrm{N} 340^{\circ}\right)$. The results are very satisfactory as we would have liked.

\subsection{SEISMIC HAZARD CALCULATED USING FAULT GEOMETRY}

As already stated, the methodology used for calculation of seismic hazard is that proposed by several authors, which uses the fault geometry to characterize seismic potential and evaluate seismic hazard.

This assessment excludes the danger caused by the background seismicity of the region. This is sufficient for areas where seismic characteristics prevent the establishment of magnitude recurrence models for known faults, which is the case in the BeniChougrane Mountains, where there is a complete lack of data. Paleo-seismic data makes it impossible to establish magnitude or paleo-seismic recurrence periods for specific faults. In addition, the historical seismicity of this region is dispersed (Fig. 1), and it is difficult to associate earthquakes with faults observed on the surface. This means that we cannot establish magnitude recurrence models for specific faults from historical seismicity data. Therefore, we have been able to include characteristic earthquake models obtained by several methods.

As already mentioned, the seismic magnitude calculation is proposed by a several authors using different models basing in the geometry of the faults (the slip zone and the length of the faults).However the nature of the faults is also taken in consideration. These methods make it possible to characterize the seismic potential and to evaluate the Peak Ground acceleration (PGA).

Vakov (1996) have used 400 earthquake events and he has excluded all events related to the subduction. According to this author, these relationships can be also used for the evaluation of earthquake mechanism types.

$$
M_{s}=4.973+1.273 \log (L),
$$

where $M_{s}$ is the surface magnitude and $L$ is the length.

Stirling and al (2010), studied strike slip earthquakes related to a lot of events worldwide recorded in regional networks (California, Mexico, New Zealand, Japan, 
China and Turkey). They recommend use this regression for strike slips faults world wild.

$$
M_{0}=1.22 * 1018 * L 5.0
$$

whose $M_{0}$ is the seismic moment (dyne-cm)

For strike-slip faults worldwide with $L<50 \mathrm{~km}$.

To Convert $M_{0}$ to $M_{w}$ we have used the equation

$$
\log \left(M_{0}\right)=16.05+1.5 M_{w}
$$

whose $M_{w}$ is the Moment magnitude.

Well and Copersmith (1994) analyze 244 of the world's 421 selected earthquakes and surfaces and sub-surfaces ruptures for less than $40 \mathrm{~km}$ depth. These earthquakes events are related to continental crustal for all mechanism types, both interpolate and intra-plate. They have proposed other formulas for calculating the maximum magnitude $M$ from the fault length $(L)$ and maximum displacement $\left(M_{d}\right)$

$$
M_{w}=6.69+0.74 \log \left(M_{d}\right)
$$

whose

$$
M_{d}=L * 0.025 \text {. }
$$

Wenousky (1983) have developed his equation from earthquakes associated with rupture lengths greater than about $15 \mathrm{~km}$, encompassing three slip types from both inter-plate and intra-plate tectonic environments. It's having been used limited in continental earthquakes like in Algeria.

- Strike-slip events

$$
\begin{aligned}
& M_{w}=5.56+0.87 \log (L), \\
& M_{w}=6.12+0.47 \log (L), \\
& M_{w}=4.11+1.88 \log (L) .
\end{aligned}
$$

Nuttli (1983) have developed this regression for mid-plate earthquakes (less than $500 \mathrm{~km}$ from the margins) for both continental and oceanic events. Magnitude-length relationships are obtained from derived fault lengths, not direct length measurements (empirical data are $M_{0}$ and magnitudes $M_{b}$ and $M_{s}$ ).

$$
\log \left(M_{0}\right)=3.65 \log (L)+21.0
$$

whose $M_{0}$ is the seismic moment (dyne-cm).

Dowrick and Rhoades (2004) have developed for New Zealand events this equation in analyzing a several earthquakes. Their results have been compared to multi regional relationships; these authors consider multiregional relationships to be a poor estimation for New Zealand data. This relation is influenced by structural restrictions placed on rupture width.

$$
M_{w}=4.73+1.53 \log (L), L \geq 6.0 \mathrm{~km} .
$$


Slemmons $(1977 ; 1982)$ calculated the magnitude $M_{s}$ from the length $L(\mathrm{~km})$ and the displacement $D(\mathrm{~cm})$ of the strike slip, normal and reverse faults by the following formulas:

\section{From the length}

Strike slip faults:

$$
\begin{aligned}
& M_{s}=1.404+1.169 \log (L), \\
& M_{s}=2.021+1.142 \log (L), \\
& M_{s}=0.809+1.341 \log (L) .
\end{aligned}
$$

Reverse faults:

Normal faults:

From the fault surface

Strike slip faults:

$$
\begin{gathered}
M_{s}=6.974+0.084 \log (D), \\
M_{s}=6.793+1.306 \log (D), \\
M_{s}=7.668+0.750 \log (D) .
\end{gathered}
$$

Normal faults:

Ambraseys and Jackson (1998), have developed an equation in the eastern Mediterranean sea for all types of strike slip, reverse and normal faults.

$$
M_{s}=5.13+1.14 \log (L) \text {. }
$$

for historical and instrumental data whose

$$
M_{w}=\left(0.67 * M_{s}\right)+2.07 .
$$

Strasser et al. (2010), have developed this regression for subduction zone events worldwide. They distinguish between interface and intra-slab events.

Relationship parameters are also available for width and length parameters as well as for area in terms of magnitude (instead of magnitudes in terms of area).

$$
\begin{gathered}
M_{w}=4.725+1.445 \log (L)(20 \text { Intra-slab events used) } \\
\text { 4.3. PEAK GROUND ACCELERATION (PGA) CALCULATED } \\
\text { USING MAGNITUDE }
\end{gathered}
$$

Maximum ground acceleration, PGA (Peak Ground Acceleration), is an important parameter for assessing the effects of earthquakes at a given location (Paleaz et al. 2003). It is measured in $\mathrm{g}$ (acceleration due to gravity) or in $\mathrm{cm}^{2} / \mathrm{s}\left(1 \mathrm{~g}=980 \mathrm{~cm} / \mathrm{s}^{2}\right)$. The amplitude of the PGA makes it possible to get an idea of the force resultant $(F)$ applied to the mass construction $(m)$, where $F=m * a$ if the construction is undeformable and moves like the ground.

PGA was calculated using the models of Cornell (1968), Esteva and Rosenblueth (1964), McGuire (1976), Campbell (1981, 1988 and 1997), Idriss (1985), Xiang and Gao (1994), Woodward and Clyde (1983) and Ambraseys (1995). 
Campbell (1981) has proposed three models to calculate the PGA

$$
\begin{gathered}
P G A=0.0159 \mathrm{e}^{0.868 M}\left(R+0.0606 \mathrm{e}^{0.7 M}\right)^{-1.09}, \\
P G A=0.0185 \mathrm{e}^{1.28 M}\left(R+0.147 \mathrm{e}^{0.732 M}\right)^{-1.75}, \\
\ln P G A=-3.99+1.28 m-1.75 \ln \left(R+0.147 \mathrm{e}^{0.732 M}\right),
\end{gathered}
$$

where $R$ is the distance from Mascara city to the seismic epicentral in $\mathrm{km}$; $M$ is magnitude, and $P G A$ in $\mathrm{g}$.

In 1988, Campbell has presented the fourth model:

$$
\ln P G A=-2.817+0.702 M-1.2 \ln \left(R+0.0921 \mathrm{e}^{0.584 M}\right) .
$$

This model is based on data from the previous 3 models. It was used, for the first time, in the calculation of PGA in the California region.

More recently, the fifth model is proposed (Campbell 1997):

$$
\begin{gathered}
\ln (A h)=-3.512+ \\
+\left(1.125-0.112 \ln \left(R_{s}\right)-0.0957 M\right) F+\left(0.440-0.171 \ln \left(R_{s}\right)\right) S_{s r} \\
+\left(0.405-0.222 \ln \left(R_{s}\right)\right) S_{h r}+\varepsilon .
\end{gathered}
$$

$A h$ is $G P A$ in $\mathrm{g} ; \varepsilon$ is the random error; $M$ is the magnitude, $R_{s}$ is the shortest distance between Mascara City and the fault area at the depth of the seismogenetic thickness.

$F$ is the factor of the fault type: $F=0$ for strike slip; $F=1$ for reverse; and $F=0.5$ for normal fault.

$S_{h r}$ and $S_{s r}$ are the dependent factors of physico-mechanical characters of the foundation:

$S_{h r}=S_{s r}=0$ for alluvium and soil; $S_{h r}=0$ and $S_{s r}=1$ for soft rocks; $S_{h r}=1$ and $S_{s r}=0$ for hard rocks.

In addition to Campbell formulas, the following others are also used to calculate $P G A$ :

Xiang and Gao model (1994):

$$
P G A=0.2529 \mathrm{e}^{0.5155 M}(R+10)-1.1516
$$

Idriss model (1985):

$$
\begin{aligned}
\ln P G A & =\ln \left(-18160.8+13144.5 M-3272.01 M^{2}+345.034 M^{3}\right. \\
& \left.-13.2363 \mathrm{M}^{4}\right)-(0.42371 M+4.5975) \ln (R+20),
\end{aligned}
$$

Woodward-Clyde model (1983):

$$
\begin{aligned}
& \ln P G A=-2.611+1.1 M-1.75 M \ln \left(R+0.3157 \mathrm{e}^{0.6286 M}\right) \text { if } M>6.5, \\
& \ln P G A=-2.611+1.1 M-1.75 M \ln \left(R+0.8217 \mathrm{e}^{0.4814 M}\right) \text { if } M . \leq 6.5,
\end{aligned}
$$


Cornell model (1968):

$$
P G A=0.863 \mathrm{e}^{0.86 M}(R+25)-1.8
$$

McGuire model (1976):

$$
P G A=0.0306 \mathrm{e}^{0.89 M} R-1.17 \exp (-0.2),
$$

Esteva and Rosenblueth model (1964):

$$
P G A=5600 \mathrm{e}^{0.8 M}(R+40)-2 / 980,
$$

Ambreseys model (1995):

$$
P G A=-1,06+\left(0.245 M_{w}\right)-(0.00045 R)-1.016 \log (R) .
$$

\subsection{INTERPOLATION}

The magnitude and PGA data obtained by several models are directly interpolated by kriging methods; indeed, we have used the kriging method because it is one of the most commonly used like geostatistical methods. Kriging, like the IDW interpolation, create weights from surrounding measured values to predict values at unmeasured locations (Travelletti et al. 2012) (Fig. 6). However unlike IDW, kriging directly incorporates spatial auto-correlation. Kriging weights come from a semivariogram, which was developed for modeling of spatial variability of a data structure (Marinoni, 2003).
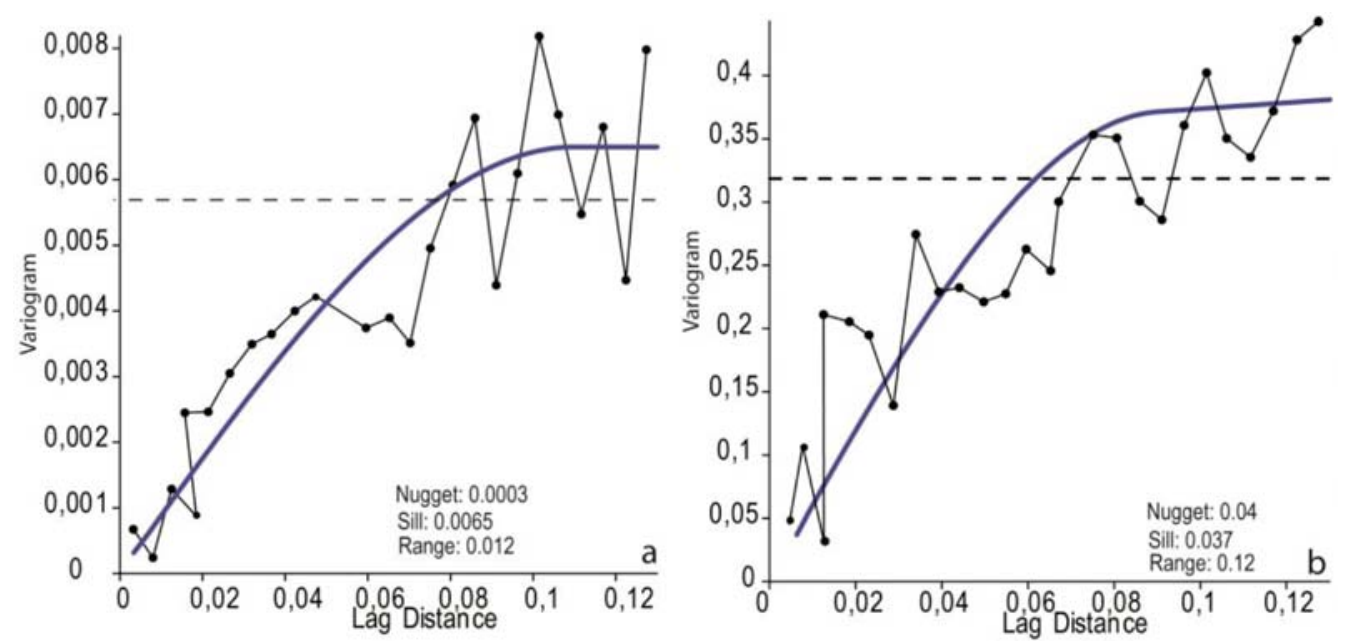

Fig. 6. The variogram model elaborated for: Magnitude (a) and PGA (b).

The distances are expressed in meters and the semi-variogram value is in magnitude degrees

(Richter scale) 
To create a map of the phenomenon, the optimal linear predictions are made for locations in the investigated area (Fig. 6). They are based on the semi-variogram and spatial arrangement of measured values that are nearby. For this purpose, we have adjusted the variogram, the range and sill was adjusted in manner to give maximum tendency to our point (Zůvala et al. 2016)(Fig. 6).

\section{RESULTS AND DISCUSSION}

The seismic risk in the Beni-Chougrane Mountains was calculated on the basis of the geometric characteristics and the nature of the known active faults, using several models to determinate magnitude (Vakov 1996; Stirling et al. 1996; Well and Copersmith 1994; Wenousky and Nuttli 1983; Dowrick and Rhoades 2004; Slemmons 1977; 1982; Ambraseys and Jackson 1998; Strasser et al. 2010) and other models for evaluating PGA (Cornell 1968; Esteva and Rosenblueth 1964; McGuire 1976; Campbell 1981; 1988; 1997; Idriss 1982; Xiang and Gao 1994; Woodward and Clyde 1983; Ambraseys 1995). The comparison of magnitudes and PGA calculated using spatially smoothed historical seismicity data and those directly derived from active faults gives significant and different results. The magnitude obtained from the instrumental seismicity varies between 2.4 and 6.1 (Fig. 7b). This finding underestimates, in some way, the seismic risk (Fig. 7b). More specifically, we obtained PGA values for a return period of 475 years, which are about half of those resulting from the seismicity obtained using the models based on the geometry of the active faults. These values could certainly be real if the movement observed in each fault occurred as established by the models.

The northern part of Mascara is characterized by a less recent tectonic activity than in the southern part; it is in particular the angular unconformities which date back to Miocene time (Fig. 5).

According to the location of the earthquake of 1967, this earthquake was located on a probably old tectonic structure and was reactivated by recent tectonic stress fields.

In the central part of the Beni-Chougrane Mountains, exactly in the Hacine/Sig axis, the calculated magnitudes show less important values ranged between 5.7 and 6.1. These values are in agreement with the values of instrumental seismic activity (Craag, CMT, USGS). Indeed, the earthquake of Hacine 1994, testifies this concordance (magnitude of 5.8) (Bezzeghoud et al. 1999; Aydai et al. 2002). This area is seismically active but the length of the tectonic fault is not very important. However, the natures of the majority of faults are strike slip.

The southern parts are represented by the abnormal contact between the Mesozoic mountains (Sidi Kada Mountains) and the Cenozoic lands (Beni-Chougrane) (Anderson et al. 1936). This contact is materialized by very important accidents. In the southwestern part, especially in the Sfisef area, this contact is materialized by reverse faults extending over very large distances, (Thintoin 1948). This deformation regime 
is the same for the southeast region of the Beni-Chougrane Mountains. The mode of deformation is a fold marked at its end by a reverse fault. This section will be detailed in our next work. In this part, the values of calculated magnitudes are very important and ranged between (6.7 to 7.3) (Fig.7a). These values correspond to interesting characteristics tectonic faults: (i) reverse faults (Sfisef faults, South Mascara fault), (ii) length exceed at $10 \mathrm{~km}$ and (iii) very deepest indeed its mark the transition between a very deformed systems in the north (Beni-Chougrane Mountains) and very stable area (Ghriss plain). Indeed, Thomas 1985 show that the structure of the Ghriss plain is a rhombus shape framed by two main faults (Sfisef and Mascara). These faults must be deep, and probably affect the basement. The Jebel Neffous and Jebel Bou Rheddou massifs are only tectonic windows attesting the importance of these faults.

The fault limiting the Ghriss Plain with the Sidi Kada Mountains can generate significant seismicity. But this seismicity will be less important compared by the magnitudes calculated near the reverse fault. The city of Mascara is characterized by important magnitude ranged from 6.4 to 6.5 at the Richter scale (Fig. 7a).

We believe that the PGA values obtained using the known active fault geometry are very significant in the Beni-Chougrane area (Fig. 7c, d). The map of accelerations to the soils, rather show two distinct zones. The first zone located in the northwestern part of the Beni-Chougrane Mountains characterized by PGA values ranged between 0.08 and 0.13 (Fig. 7c). The most important values are recorded around the city of Mascara with values between 0.13 and 0.31 (Fig. 7c). Because of its position on the highly deformed southern flank of the Beni-Chougrane Mountains, the city of Mascara is located in the area closest to the seismic source which can been generated by a lot of reverse faults. These faults can be responsible for larger earthquakes with great magnitudes (6.7 to 7.3 ) (Fig.7a).

As we can see in Fig. 7, the highest values of PGA (more than 0.34, 0.44 and $0.54 \mathrm{~g}$ ) are found in the center of the Beni-Chougrane area. In other parts of Mascara province, as well as in Sfisef, the PGA values are between 0.16 and 0.18 . These values correspond to the probable seismicity related to the Sfisef fault. The value of this parameter decreases in the NW part of the Beni-Chougrane Mountains, where values reach almost 0.06 to $0.08 \mathrm{~g}$.

In the North African part, the oldest stress that was NE/SW at the Pliocene. However, it is oriented now NNW/SSE (Meghraoui and Pondrelli 2013). The stress regime is compressive from Tortonian to present times. This compression induced by the African plate motion is responsible of all stage of deformation in its northern part (Atlasic and Tellian Chain); it's also the origin of the seismicity that affects the Tellian Chain. Indeed, in the Beni-Chougrane Mountains, the micro-seismicity is generally due to the fact that the NE/SW and NW/SE faults facilitate the shortening oriented NNW/SSE (Fig. 2), however, it is important to note that the Slip is much more significant in NW/SE faults than NE/SW faults. This fact is due to the obliquity of the tectonic stress with respect to the line of the movement of the fault. This 
zone has both NNW/SSE horizontal compression and a substantially perpendicular extension, which generally causes the exhumation of Beni-Chougrane chain along an $\mathrm{N} 70^{\circ}$ structure axis. The southern parts of the folds are always marked by reverse faults often oriented $\mathrm{N} 70^{\circ}$. These faults are associated with very high calculated magnitudes. As early as the Tortonian compression, the installation of the basin of the Ghriss plain considered as a Pull-apart basin is due to a transtension along fault ENE/WSW in the north and faults oriented E-W in the south. The Sidi Kada fault marks a clear boundary between a Tellian domain in the North and a Tlemcian domain in the South. The long lengths of these faults are at the origin of their more or less remarkable seismicity.

The clockwise rotation of the blocks highlighted in the Chlef region (Ex Asnam) can generate inverse faults due to the lateral overlapping movement of the blocks (Meghraoui 1986). Thus, faults oriented NE/SW could develop. For this purpose, the seismicity obtained from the active faults seems to me very realistic.

Another problem is that fibrous growths of minerals such as calcite, gypsum or iron oxides are found on the exposed surfaces of the faults, indicating the direction of fault compartments movement. This feature is not consistent with abrupt movements and requires slow and continuous displacements, indicating that part of the fault motion is aseismic creep (Behr et al. 1990; Deng and Sykes 1997; Beeler et al. 2001; Dragert et al. 2001).
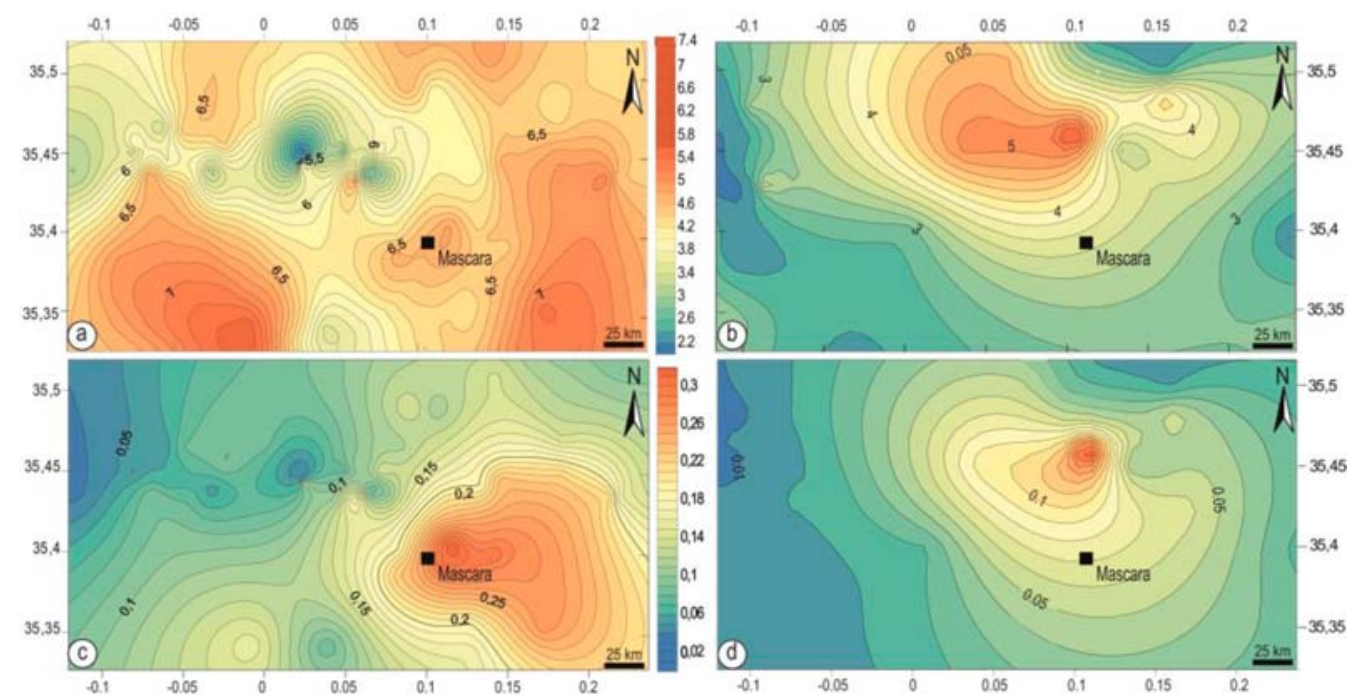

Fig. 7. Maps showing magnitude and Probabilistic seismic hazard: a - maps derived from measured data, $\mathrm{b}$ - map obtained by calculating magnitude in basis of multiple regression models,

$\mathrm{c}$ - Median PGA based on the seismicity data alone and d-PGA calculating from fault data alone, in both cases for a return period of 475 years ( $10 \%$ exceedance probability in 50 years).

The black square shows the position of Mascara town 
Detailed paleo-seismic studies are recurred for each fault to determine its paleoseismicity. New segmentation studies of these faults will also be recurred.

The continuous faults surrounding the Beni-Chougrane Mountains are parallel and partly staggered (Fig. 2).

The seismic catalogs of the western part of Algeria are not really complete and the oldest values are estimated from subjective intensities. In some countries, the catalogs are the most complete for 100 or 150 years, even for medium and large sizes. For this purpose, the quantities obtained from the active faults data complete these differences in magnitudes.

However, in the rest of Algeria, especially in the central area, we have more or less complete catalogs for a period that goes back more than 1000 years.

Indeed, in some areas of the Beni-Chougrane Mountains, we are certain that a destructive earthquake (above $0.4 \mathrm{~g}$ ) has not failed in this area during the last 1000 years.

\section{CONCLUSION}

The Beni-Chougrane zone is a tectonically active zone; it was the seat of some violent earthquakes. Indeed, the magnitudes are more or less modest; however the type of construction built remains to be desired. In this goal, the good knowledge of this phenomenon can be useful to effectively protect people and people's property. It is for this purpose that we think that tectonic structures require better knowledge to understand and minimize the devastating effects of earthquakes. To do this, we calculated the seismic risk in the Beni-Chougrane Mountains based on the known characteristics of the faults, using several models. The elaborated maps were compared to spatially smooth instrumental seismicity data (Pelaez and Lopez Casado 2002; Pelaez et al. 2003). The results are more or less disturbing especially when we know that the obtained PGA values oscillate between 0.003 and $0.3 \mathrm{~g}$, about twice as much as those of instrumental seismicity alone.

These values of risk could certainly be reached if the calculated magnitude actually occurs. Indeed, these values of magnitude are more important, they oscillate between 4.8 and 7.25 on the Richter scale, which could be real since the zone Beni-Chougrane is in the same context as that of the Chlef zone characterized by the greatest magnitude never recorded in Algeria (7.3).

In the current state of our knowledge, any study has been undertaken to analyze the seismicity in the Beni-Chougrane region. These are the reasons why we prefer to show the results separately and not summed up. We are fully confident about the results obtained from the only seismic data, but we believe that those obtained from the active faults data are still far from being definitive. 


\section{ACKNOWLEDGEMENTS}

We would like to thank the local authorities of the Mascara department, especially those of the Housing and Urban Planning Department (DUCH); we also warmly thank the Water Resources Services (DRE) for allowing us access to their archives of geophysical data. We also would like to thank the anonymous experts for evaluating this work.

We also thank the editor and the anonymous reviewers for helping improve the quality of our manuscript.

\section{REFERENCES}

AMBRASEYS N.N., 1995, The prediction of earthquake peak ground acceleration in Europe, Earthquake Engineering and Structural Dynamics, 24 (4), 467-490.

AMBRASEYS N.N., Jackson J.A., 1998, Faulting associated with historical and recent earthquakes in the Eastern Mediterranean region, Geophys. J. Int., 133 (2), 390-406.

ANDERSON R.V., 1936, Geology in the coastal atlas of western Algeria, Memoir of the Geological Society of America, New York, 4, 1-450.

AYADI A., OUSADOU-AYADI F., BOUROUIS S., BENHALLOU H., 2002, Seismotectonics and seismic quietness of the Oranie region (Western Algeria), The Mascara earthquake of August 18th, 1994, $M_{w}=5.7, M_{s}=6.0$, J. Seismol., 6, 13-23.

BENOUAR D., AOUDIA A., MAOUCHE S., MEGHRAOUI M., 1994, The 18 August 1994 Mascara (Algeria) earthquake, a quick-look report, Terra Nova, 6, 634-638.

BEZZEGHOUD M., BUFORN E., 1999, Source parameters of the 1992 Melilla (Spain, $M_{w}=4.8$ ), 1994 Alhoceima (Morocco, $M_{w}=5.8$ ), and 1994 Mascara (Algeria, $M_{w}=5.7$ ) earthquakes and seismotectonic implications, Bulletin of the Seismological Society of America, 89 (2), 359-372.

BEZZEGHOUD M., AYADI A., SEBAÏ A., AÏT-MESSAOUD M., MOKRANE A., BENHALLOU H., 1996, Seismicity of Algeria between 1365 and 1989: Map of maximum observed intensities (MOI), Avancesen Geofisica y Geodesia, 1, 107-114.

CAMPBELL K.W., 1988, The Whittier Narrows, California earthquake of October 1, 1987 - preliminary analysis of peak horizontal acceleration, Earthquake Spectra, 4 (1), 115-137.

CAMPBELL K.W., 1989, The dependence of peak horizontal acceleration on magnitude, distance, and site eects for small-magnitude earthquakes in California and eastern North America, Bulletin of the Seismological Society of America, 79 (5), 1311-1346.

CAMPBELL K.W., 1981, Near-Source Attenuation of Peak Horizontal Acceleration, B. Seism. Soc. Am., 71 (6), 2039-2070.

CAMPBELL K.W., 1997, Empiritical near source attenuation relationship of horizontal and vertical component of peak ground acceleration, peak ground velocity and pseudo absolute acceleration response spectra, Seismo. Research Letters, 68 (1).

CORNELL C.A., 1968, Engineering seismic risk analysis, Bulletin of the Seismological Society of America, 58 (5), 1583-1606.

DALLONI M., 1936, Carte géologique de Mascara, Service de la carte géologique de l'Algérie, Mascara - 212.

DELTEIL J., 1974, Tectonique de la chaîne alpine en Algérie d'après l'étude du Tell oranais oriental (Monts de la Mina, Béni-Chougrane, Dahra), Thèse Doct. es Sciences, Univ. Nice, p. 294.

DOWRICK D.J., Rhoades D.A., 2004. Relations between earthquake magnitude and fault rupture dimensions: How regionally variable are they?, Bulletin of the Seismological Society of America, 94 (3), 776-788.

ESTEVA L., ROSENBLUETH E., 1964, Espectros de temblores a distancias moderadas y grandes, Boletin Sociedad Mexicana de Ingenieria Sesmica, 2 (1), 1-18. 
Etude hydrogéologique quantitative du plateau de Mascara, 1969, (2ème rapport): Estimation des potentialités en eau/SES. - Alger: Service des Etudes Scientifiques, BA.

Global CMT Catalog Search, the 18 th mascara earthquake (http://www.globalcmt.org/CMTsearch.html).

HADJI R., BOUMAZBEUR A., LIMANI Y., BAGHEM M., CHOUABI A., 2013, Geologic, topographic and climatic controls in landslide hazard assessment using GIS modeling: A case study of Souk Ahras region, NE Algeria, Quaternary International, 302, 224-237.

HADJI R., RAÏS K., GADRI L., CHOUABI A., HAMED Y., 2017, Slope failures characteristics and slope movement susceptibility assessment using GIS in a medium scale: a case study from Ouled Driss and Machroha municipalities, Northeastern of Algeria, Arabian Journal for Science and Engineering, 42, 281-300.

HANKS T.C., KANAMORI H., 1979, A moment magnitude scale, Journal of Geophysical Research, Vol. 82, 2981-2987.

HARBI A., BENHALLOU H., 2006, Evaluation de l'Aléa Sismique en Algérie du Nord par la Modélisation de l'Input Sismique dans les Zones Urbaines et l'Etablissement d'un Catalogue (Doctoral dissertation).

IDRISS I.M., 1985, Evaluating seismic risk in engineering practice, p. 255-320, [in:] Proceeding of the 11 th International conference on soil mechanics and foundation engineering, San Francisco, 12-16 août 1985, A.A. Balkema, Rotterdam, Vol. 1, 390 p.

KARIM Z., HADJI R., HAMED Y., 2018, GIS-Based Approaches for the Landslide Susceptibility Prediction in Setif Region (NE Algeria), Geotechnical and Geological Engineering, 37, 359, https://doi.org/ 10.1007/s10706-018-0615-7.

MAHDADI F., BOUMEZBEUR A., HADJI R., KANUNGO D.P., ZAHRI F., 2018, GIS-based landslide susceptibility assessment using statistical models: a case study from Souk Ahras province, NE Algeria, Arabian Journal of Geosciences, 11 (17), 476.

MANCHAR N., BENABBAS C., HADJI R., BOUAICHA F., GRECU F., 2018, Landslide Susceptibility Assessment in Constantine Region (NE Algeria) by Means of Statistical Models, Studia Geotechnica et Mechanica, 40 (3), 208-219.

MARINONI O., 2003, Improving geological models using a combined ordinary-indicator kriging approach, Engineering Geology, 69 (1), 37-45.

MCGUIRE R.K., 1976, FORTRAN computer program for seismic risk analysis, U.S. Geol. Survey open - File Rept., 76-67.

MCKENZIE D., 1972, Active Tectonics of the Mediterranean Dan. Publication: Geophysical Journal, Vol. 30, Issue 2, pp. 109-185, Publication Date: 12/1972, Origin: CROSSREF, DOI: 10.1111/j.1365-246X.1972.

MEGHRAOUI M., 1982, Etude néotectonique de la région NE d'El-Asnam: relation avec le séisme du 10 octobre 1980 (Doctoral dissertation, Thèse 3eme Cycle, University of Paris, 7, 210.

MEGHRAOUI M., PONDRELLI S., 2013, Active faulting and transpression tectonics along the plate boundary in North Africa, Annals of Geophysics, 55 (5).

MEGHRAOUI M., 1988, Géologie des zones sismiques du Nord de l'Algérie: Paléosismologie, tectonique active et synthèse sismotectonique (Doctoral dissertation, Paris 11).

MEGHRAOUI M., CISTERNAS A., PHILIP H., 1986, Seismotectonics of the lower Cheliff basin: structural background of the El Asnam (Algeria) earthquake, Tectonics, 5 (6), 809-836.

MONTILLA J.A.P., DE GALDEANO C.S., CASADO C.L., 2003, Use of active fault data versus seismicity data in the evaluation of seismic hazard in the Granada Basin (Southern Spain), Bulletin of the Seismological Society of America, 93 (4), 1670-1678.

MONTILLA J.A.P., DE GALDEANO C.S., CASADO C.L., 2003, Use of active fault data versus seismicity data in the evaluation of seismic hazard in the Granada Basin (Southern Spain), Bulletin of the Seismological Society of America, 93 (4), 1670-1678.

MOUSSA K., 1996, Le Miocene de la bordure Nord des monts de Béni-Chougrane: Etude Stratigraphique et Sedimentologique du secteur: Bou Ziri-Oued El Hammam, These de Magister, université d'Es-Senia Oran, 206 p. 
NEURDIN-TRESCARTES J., 1992, Le remplissage sédimentaire du bassin Néogène du Chélif, modèle de référence de bassins intramontagneux (Doctoral dissertation, Pau).

NEURDIN-TRESCARTES J., 1993, Evolution du bassin néogène du Chélif (Algérie nord-occidentale). Un exemple d'interaction sédimentation-tectonique, [in:] Bassins sédimentaires africains, Géodynamique et géologie séquentielle, biominéralisation, sédimentation et organismes, $4{ }^{\circ}$ Colloque de géologie africaine, Pau, pp. 25-29.

NUTTLI O.W., 1983, Average seismic source-parameter relations for mid-plate earthquakes, Bulletin of the Seismological Society of America, 73 (2), 519-535.

PELAEZ J.A., LÓPEZ C., HENARES J., 2002, Deaggregation in magnitude, distance, and azimuth in the south and west of the Iberian Peninsula, Bull. Seism. Soc. Am., 92, 2177-2185.

PERRODON A., 1957, Etude géologique des bassins néogènes sublittoraux de l'Algérie occidentale (Doctoral dissertation).

ROTHÉ J.P., DECHEVOY N., SELTZER P., 1950, Les séismes de Kerrata et la séismicité de l'Algérie, Pauc.

SLEMMONS D.B., 1977, State-of-the-Art for Assessing Earthquake Hazards in the United States, Report 6, Faults and Earthquake Magnitude (No. WES-MP-S-73-1-6), Mackay school of mines renonv.

SLEMMONS D.B., 1982, Determination of design earthquake magnitude for micronation, p. 119-130, [in:] University of Washington (réd.), Proceedings of the 3rd International Earthquake Microzonation Conference, Seattle, 28 juin-1er juillet 1982, Earthquake Society, Vol. 1, 805 p.

STIRLING M.W., WESNOUSKY S.G., SHIMAZAKI K., 1996, Fault trace complexity, cumulative slip, and the shape of the magnitude frequency distribution for strike slip faults: A global survey, Geophysical Journal International, 124 (3), 833-868.

STRASSER F.O., ARANGO M.C., BOMMER J.J., 2010, Scaling of the Source Dimensions of Interface and Intraslab Subduction-zone Earthquakes with Moment Magnitude, Seism. Res. Lett., 81 (6), 941-950.

THOMAS G., 1979, Sur l'existence d'une compression intra-miocène post-nappe dans le Tell méridional oranais (Algérie), CR Somm. Soc. Géol. France, 2, 56-59.

THOMAS G., 1985, Géodynamique d'un bassin intramontagneux. Le Bassin du Bas Chélif occidental (Algérie) durant le Mio-Plio-Quaternaire, Thèse Es-Sciences, Pau, 594 p., 162 figs., 32 tabl., 3 pl. h.t.

TRAVELLETTI J., DELACOURT C., ALLEMAND P., MALET J.P., SCHMITTBUHL J., TOUSSAINT R., BASTARD M., 2012, Correlation of multi-temporal ground-based optical images for landslide monitoring: Application, potential and limitations, ISPRS Journal of Photogrammetry and Remote Sensing, 70, 39-55.

USGS 1994, US Geological Survey, the 18th 1994 Mascara earthquake data.

VAKOV A.V., 1996, Relationships between earthquake magnitude, source geometry and slip mechanism, Tectonophysics, 261 (1), 97-113.

WELLS D.L., COPPERSMITH K.J., 1994, New empirical relationships among magnitude, rupture length, rupture width, rupture area, and surface displacement, Bulletin of the seismological Society of America, 84 (4), 974-1002.

WESNOUSKY S.G., SCHOLZ C.H., SHIMAZAKI K., MATSUDA T., 1983, Earthquake frequency distribution and the mechanics of faulting, J. Geophys. Res., 88 (B11), 9331-9340.

WOODWARD-CLYDE C., 1983, Seismic exposure study, offshore, southern California, Report to Texaco USA, New Orleans, $178 \mathrm{p}$.

WYSS M., 1979, Estimating maximum expectable magnitude of earthquake from faul dimension, Geology, Vol. 7, No. 7, 336-340.

XIANG J., GAO D., 1994, The strong ground motion records obtained in Lancang-Gengma earthquake in 1988, China, and their application, Rept. at International Workshop on Seismotectonics and Seismic Hazard in Southeast Asia, Hanoi.

YELLES-CHAOUCHE A., BOUDIAF A., DJELLIT H., BRACENE R., 2006, La tectonique active de la région nord-algérienne, Comptes Rendus Geoscience, 338 (1), 126-139.

ZU゚VALA R., FIŠEROVÁ E., MAREK L., 2016, Mathematical aspects of the kriging applied on landslide in Halenkovice (Czech Republic), Open Geosciences, 8 (1), 275-288. 